\title{
OPTIMIZATION OF TRAINING MODULES CHOICE DURING MULTIPURPOSE TRAINING OF SPECIALISTS
}

\author{
V.V. Menshikh, E.N. Sereda \\ Voronezh Institute of the Ministry of the Interior of the Russian Federation, Voronezh, \\ Russian Federation \\ E-mail: menshikh@list.ru, sereda-en@mail.ru
}

The article is devoted to the problems of mathematical modelling of the processes of organizing multipurpose learning. Under the multipurpose training is understood such an organization of the educational process, in which in one group specialists are trained in several related areas of activity, trajectory of training for which at certain intervals intersect. In order to reduce the total training time, as well as the cost or resources required in the training process, it is expedient to carry out the dynamic grouping of students by subgroups in order to master certain competences.

The development of the mathematical apparatus used to optimize the multipurpose learning process has not been completely studied at present. To reduce the dimension of the overall task of optimizing the process of organizing multipurpose training, its step-bystep solution is proposed. The article describes the approach to calculating estimates of the possibility of training specialists in the areas of training and selection of training modules available in the educational organization. The paper considers the options for optimizing the selection of modules for training specialists on the following criteria: minimizing the total duration of training, the cost of training and resources used for training. The algorithm with the help of which it is possible to form an optimal group of students is proposed.

Keywords: multipurpose training simulation; field of training; optimization; assignment problem.

\section{Introduction}

The accelerated rate of introducing scientific and technological achievements into various areas of human activity calls for improved training (retraining) of specialists obtaining both basic and specialized competences [1]. Some of the competences may apply to several specialists, and another is unique and is expressed, for example, in just one specialist. The issue of training and retraining of such specialists is rather expensive. In this situation, good prospects are shown by formation of the specialist multipurpose training groups in close areas of activity $[2,3]$. Their formation is grounded by the fact that the training paths of the mentioned groups of specialists partially intersect. This makes it possible to create temporary subgroups for mastering some competences [4].

In this case, some specialists may have formed certain competences prior to the beginning of the training, which is the ground for selecting for them such fields of training that will be covered within the shortest period of time and (or) will require minimal resources. Apart from this, there may exist some restrictions characterizing the qualification requirements to the abilities to perform certain roles, which complement those requirements to the specialists that are not accounted for the competences (availability of field-specific education, record of service, practical experience associated with the role, etc.) $[5]$.

For simulation of the specialist group multipurpose training it is necessary to use the sets $L=l_{1}, \ldots, l_{|L|}$ - trainees, $N=n_{1}, \ldots, n_{|N|}$ - fields of training, $K=k_{1}, \ldots, k_{|K|}-$ 
competences that exist or must be formed in the trainees, $M=m_{1}, \ldots, m_{|M|}$ - training modules, each allowing forming one or several competences.

The general problem of organizing the multipurpose training has a large dimension, which makes it almost impossible implement the global optimization. In this case, it is expedient to use various reduction methods involving sequential optimization of individual groups of the general problem parameters. This paper considers three options for optimizing the choice of modules for training the specialists: by the criteria of minimization of the total training duration, the training cost, and the resources used for training. The mentioned task particularly requires specialists distribution optimization by the fields of training.

\section{Problem Statement and Formalization}

Each field of training $n_{i}, i=1, \ldots,|N|$ is associated with a list of competences the specialist should have.

We will assume that the competences $k_{j}, j=1, \ldots,|K|$ have restrictions imposed on the sequence of their formation. In order to simplify the mathematical model of the training process, we will consider each level of formation [6] of a competence to be an independent competence, which can take the following values: 1 - competence is formed, 0 -competence is not formed.

By the training module $m_{k}, k=1, \ldots,|M|$ we will understand a discipline, a subdiscipline, a separate topic etc. The modules are executed in a certain sequence and are aimed at forming one or several interconnected competences. The modules also include individual work modules, and their purpose is to improve the existing competences.

A set of modules is characterized by the times of execution $T=\left(t\left(m_{1}\right), \ldots, t\left(m_{|M|}\right)\right)$, the cost $C=\left(c\left(m_{1}\right), \ldots, c\left(m_{|M|}\right)\right)$, and requires the known in advance set of resources $\vec{R}=\left(\vec{r}\left(m_{1}\right), \ldots, \vec{r}\left(m_{|M|}\right)\right)[7,8]$. Several alternative options of the training modules can be used for obtaining some competences. For example, availability of simulators allows saving the training time, but increases the involved resources and limits the number of trainees simultaneously mastering the respective module.

We should assign to the resources the availability in the educational organization that performs the training process of the following: material and technical basis (laboratories, simulators etc.), competent academic staff with an appropriate level of training, technical means for training, etc.

Taking into account the necessity to solve the resource minimization problem, it can be represented in a scalar form as a generalized resource

$$
R=\sum_{k=1}^{|M|} \alpha_{k} r\left(m_{k}\right),
$$

representing a weighted sum of various kinds of resource. The weight coefficients $\alpha_{k}$ are assigned subject to the importance of certain kinds of resource, which can be implemented, for example, using the hierarchy analysis method [9].

Let us consider the issue of choice of the optimal option for distribution of the trainees by the fields of training. The aforementioned grouping should correspond to one of the three options of the training process optimization: 
1) minimization of the total time $T$ with restrictions on the cost $\hat{C}$ and the resource $\hat{\vec{R}}$, allocated for the educational process for the given group of trainees;

2) minimization of the training cost $C$ with restrictions on the total time $\hat{T}$ and the resource $\hat{\vec{R}}$;

3) minimization of the generalized resource $R$ for ensuring the educational process in the given group with restrictions on the time $\hat{T}$ and the training cost $\hat{C}$.

The problem is solved in two steps:

at the first step, we determine the estimates of the ability to form in the trainees the competences corresponding to the respective fields of training;

at the second step, we determine the optimal option for trainees grouping based on their fields of training.

\section{Estimates of the Training Ability in the Respective Fields}

Let the test results show that a trainee $l_{j}$ has a set of competences $K\left(l_{j}\right) \subseteq K$ and the $s$ th field of training requires possession of the set of competences $K_{s}^{0} \subseteq K$. Then, for training of the specialist $l_{j}$ in the $s$-th field, require that he masters the set of competences $K_{s}\left(l_{j}\right)=$ $K_{s}^{0} \backslash K_{0}\left(l_{j}\right)$. Apart from this, we should take into account the additional restrictions $o_{j s}$ on the possibility to train $l_{j}$ in the $s$-th field of training:

$$
o_{j s}= \begin{cases}1, & \text { if the } j \text {-th trainee can be assigned to the } s \text {-th field of training, } \\ 0, & \text { it otherwise }\end{cases}
$$

Considering the relation between the competences and the training modules for each $k_{p} \in K_{s}\left(l_{j}\right)$ to be specified, we will find the set of all modules ensuring obtaining of the given competence $M\left(k_{p}\right) \subseteq M$. Considering that the modules can form several competences simultaneously, their abilities to form competences may be partially or even fully duplicated. Therefore, alternative options of training in these modules are possible. Now let us turn to finding and estimation of the mentioned alternative options.

A part of the competences may be formed by a non-alternative method. The respective modules $M^{\prime}\left(k_{p}\right) \subseteq M$ are necessarily included in the training programme.

After this, all the competences $K_{s}^{\prime}\left(l_{j}\right) \subseteq K_{s}\left(l_{j}\right)$ are determined, whose formation is ensured by the modules of the set $M^{\prime}\left(k_{p}\right)$.

Admissibility of using the modules $M^{\prime}\left(k_{p}\right)$ for training in the $s$-th field of training is determined as a result of checking the restrictions for the respective training process option.

Let us denote $\tilde{M}\left(k_{p}\right)=M\left(k_{p}\right) \backslash M^{\prime}\left(k_{p}\right), \tilde{K}_{s}\left(l_{j}\right)=K_{s}\left(l_{j}\right) \backslash K_{s}^{\prime}\left(l_{j}\right)$. The problem reduces to finding the modules from the set $\tilde{M}\left(k_{p}\right)$, which form the set of competences $\tilde{K}_{s}\left(l_{j}\right)$ in accordance with one of the above-mentioned options of the training process optimization.

The solution of the problem is such a subset $M^{\prime \prime}\left(k_{p}\right)$ of the set $\tilde{M}\left(k_{p}\right)$, which ensures obtaining the entire set of competencies $\tilde{K}_{s}\left(l_{j}\right)$ and minimizes either the estimate of the total training time of the specialist $l_{j}$ in the $s$-th field of training, which is determined by the formula

$$
T_{j s}=\sum_{m_{k} \in M^{\prime}\left(k_{p}\right)} t\left(m_{k}\right)+\sum_{m_{k} \in M^{\prime \prime}\left(k_{p}\right)} t\left(m_{k}\right)
$$


or the estimate of the training cost by the formula

$$
C_{j s}=\sum_{m_{k} \in M^{\prime}\left(k_{p}\right)} c\left(m_{k}\right)+\sum_{m_{k} \in M^{\prime \prime}\left(k_{p}\right)} c\left(m_{k}\right)
$$

or the estimate of the generalized resource

$$
R_{j s}=\sum_{m_{k} \in M^{\prime}\left(k_{p}\right)} r\left(m_{k}\right)+\sum_{m_{k} \in M^{\prime \prime}\left(k_{p}\right)} r\left(m_{k}\right) .
$$

If the number of such subsets $2^{\left|\tilde{M}\left(k_{p}\right)\right|}$ is not great, then the subset $M^{\prime \prime}\left(k_{p}\right)$, ensuring obtaining of the minimal values, can be found as the exact solution of the problem by the exhaustive method. If the problem solution time is inadmissibly great, then the last found solution can be chosen as an approximate one.

Let us consider a numerical example that elucidates the described method.

Suppose that for training of the trainee $l_{j}$ it is required to master the competences $k_{1}, k_{2}, k_{3}, k_{4}$. This can be ensured with the help of the modules, whose description and abilities to form competences are represented in Table 1.

Table 1

Description of training modules

\begin{tabular}{|c|c|c|c|c|c|c|}
\hline Notation & Time, conventional units & Generalized resource & $k_{1}$ & $k_{2}$ & $k_{3}$ & $k_{4}$ \\
\hline$m_{1}$ & 10 & 5 & 1 & 0 & 0 & 0 \\
\hline$m_{2}$ & 6 & 5 & 0 & 1 & 0 & 0 \\
\hline$m_{3}$ & 6 & 5 & 0 & 0 & 1 & 1 \\
\hline$m_{4}$ & 10 & 15 & 0 & 1 & 1 & 1 \\
\hline$m_{5}$ & 8 & 12 & 0 & 1 & 0 & 1 \\
\hline
\end{tabular}

The competence $k_{1}$ can only be obtained using the module $m_{1}$. Therefore, it is mandatory to choose this module.

The other competences can be obtained by three methods:

the 1st method - with the help of the modules $m_{2}$ and $m_{3}$,

the 2nd method - with the help of the module $m_{4}$,

the 3rd method - with the help of the modules $m_{3}$ and $m_{5}$.

The first competence forming method ensures minimization of the resource costs $(15$ conventional units), while the second method ensures minimization of the total time (18 conventional units of time). The third method is inefficient by any of the criteria.

\section{Optimization of the Choice of Field of Training}

Let us introduce variables:

$$
\begin{aligned}
& X=\left\{x_{j s}\right\}_{j=1, \ldots,|L| ; s=1, \ldots,|N|}, \text { where } \\
& x_{j s}= \begin{cases}1, & \text { if the } j \text {-th trainee is assigned to the } s \text {-th field of training, } \\
0, & \text { if otherwise. }\end{cases}
\end{aligned}
$$


When distributing the trainees by the fields of training, the following conditions [10] should be observed that take into account the qualification requirements:

1) only one trainee should be assigned to one field of training, i.e.

$$
\sum_{j=1}^{|L|} x_{j s} o_{j s}=1
$$

2) each trainee can be assigned to no more than one field of training

$$
\sum_{j=1}^{|L|} x_{j s} O_{j s} \leq 1
$$

3) each trainee can only be assigned to the field of training he is admitted to

$$
\forall j \forall s x_{j s} \leq o_{j s}
$$

Then, the problem of choosing the entire group of trainees has the following form:

1) find

$$
X^{*}=\underset{s \in N}{\arg \min } \sum_{j=1}^{|L|} x_{j s} T_{j s}
$$

with restrictions $(1)-(3)$, if the training time is to be minimized;

2) find

$$
X^{*}=\underset{s \in N}{\arg \min } \sum_{j=1}^{|L|} x_{j s} C_{j s}
$$

with restrictions $(1)-(3)$, if the training cost is to be minimized;

3) find

$$
X^{*}=\underset{s \in N}{\arg \min } \sum_{j=1}^{|L|} x_{j s} R_{j s}
$$

with restrictions $(1)-(3)$, if the generalized resource required for training is to be minimized.

These problems can be interpreted as assignment problems, which allows using an algorithm based on the results of the work [11].

Step 0. Assign each trainee to the field of training in which he can be trained within the shortest time (with the minimal cost or the minimal resource), where

$$
x_{j s}^{0}= \begin{cases}1, & \text { if } T_{j s}=\min _{k} T_{k s}, \\ 0, & \text { if otherwise }\end{cases}
$$

If, in this case, all nodes of the set $N$ are covered and restrictions (3) - (5) are fulfilled, then the optimal distribution of the trainees by the field of training is found. If no trainee is assigned to some field of training, then the problem is not solved. Hence, we proceed to step $k$. 
Step $k$. Introduce the subsets of edges

$$
\begin{aligned}
& F_{1}=\left\{(j, s) \mid x_{j s}=1\right\}, \\
& F_{2}=\left\{(j, s) \mid x_{j s}=0\right\} .
\end{aligned}
$$

Form a net, where the set of nodes indicating the fields of training to which several trainees are assigned will be taken as the net input; and the set of nodes indicating the fields of training to which none of the trainees is assigned will be taken as the net output. Change the directions of the edges from the subset $F_{1}$ for the opposite ones, take their length equal to $\left(-T_{j s}\right)$, while the lengths of the edges from the subset $F_{2}$ is equal to $T_{j s}$. In the obtained net, find the path of the minimal length $\mu^{k}$.

Then calculate:

$$
x_{j s}^{k}= \begin{cases}x_{j s}^{(k-1)}, & \text { if }(j, s) \notin \mu^{k}, \\ 1-x_{j s}^{(k-1)}, & \text { if }(j, s) \in \mu^{k} .\end{cases}
$$

Step $k$ is repeated until the optimal value is found.

\section{Conclusion}

The described module and algorithm allow to determine the modules expedient to use for the multipurpose specialists training in various fields, which will later facilitate choosing individual training paths for each of them. The said paths should represent sequences of actions for implementation of the training modules. For each action, the subgroups of trainees should be determined, whose choice optimization will ensure the optimization of the entire multipurpose training process, which is the aim of the further researches.

\section{References}

1. Zimnyaya I.A. [Key Competences - the New Paradigm of the Result of Education]. The Higher Education Today, 2003, no. 5, pp. 34-42. (in Russian)

2. Kiriakidis P., Barber P., Decota J.W. Research in Multidimention Education. Iasi, Lumen, 2011.

3. Kelly K.P., Johnson-Freese J. Getting to the Goal in Professional Military Education. ORBIS, 2014, vol. 58, no. 1, pp. 119-131. DOI: 10.1016/j.orbis.2013.11.009

4. Denks K.A., Yakunin Yu.Yu., Yareschenko D.I. [The Problem of Synthesizing Individual Training Plans in the Space of Virtual Training Groups]. Economics, Statistics and Informatics, 2015, no. 6, pp. 118-127. (in Russian)

5. Menshikh V.V., Sereda E.N. [Conceptual Model and Methods of Coaching Personnel in Taking Quick Collective Decisions of Emergencies Break Out]. Trudy Academii upravlenia MVD Rossii, 2016, no. 2, pp. 51-56. (in Russian)

6. Pakharenko N.V., Zolnikova I.N. [A Model for Determining the Formation Level of General Cultural and Professional Competencies]. Modern Problems of Science and Education, 2012, no. 6. Available at: https://www.science-education.ru/ru/article/view?id $=7502$ (accessed February 9, 2018). (in Russian)

7. Menshikh V.V., Sereda E.N., Kopylov A.N. [Modelling of the Trajectory Selection Processes for Training Police Officers to Act in an Emergency]. Vestnik of Voronezh Institute of the Ministry of Interior of Russia, 2016, no. 2, pp. 203-212. (in Russian) 
8. Borodin D.K., Tokarev A.V. [Educational Process Planning Software]. Quality. Innovation. Education, 2008, no. 8 (39), pp. 5-14. (in Russian)

9. Saaty T.L. Decision Making for Leaders: The Analytical Hierarchy Process for Decisions in a Complex World. Wadsworth, 1988.

10. Menshikh V.V., Sereda E.N., Samorokovskiy A.F. [The Model of Group Formation for Role Traning to Take Managerial Decisions]. Vestnik of Voronezh Institute of the Ministry of Interior of Russia, 2015, no. 2, pp. 107-114. (in Russian)

11. Burkov V.N., Gorgidze I.A., Lovetskiy S.E. Prikladnyye zadachi teorii grafov [Applied Problems of Graph Theory]. Tbilisi, Computantional Center of the Academy of Science of Georgian Soviet Socilist Republic, 1974. (in Russian)

Received January 25, 2018

УДК 519.168

DOI: $10.14529 / \mathrm{mmp} 180103$

\title{
ОПТИМИЗАЦИЯ ВЫБОРА МОДУЛЕЙ ОБУЧЕНИЯ ПРИ МНОГОЦЕЛЕВОЙ ПОДГОТОВКЕ СПЕЦИАЛИСТОВ
}

\author{
В.В. Менъших, Е.Н. Середа \\ Воронежский институт МВД России, г. Воронеж, Российская Федерация
}

\begin{abstract}
Статья посвящена вопросам математического моделирования процессов организации многоцелевого обучения. Под многоцелевым обучением понимается такая организация учебного процесса, при которой в одной группе готовятся специалисты по нескольким родственным направлениям деятельности, траектории обучения по которым в определенные промежутки времени пересекаются. С целью сокращения общего времени обучения, а также стоимости или ресурсов, требуемых в процессе обучения, для освоения некоторых компетенций целесообразно осуществлять динамическое перераспределение обучающихся по подгруппам.

Вопросы разработки математического аппарата, используемого для оптимизации процесса многоцелевого обучения, в настоящее время изучены недостаточно. Для снижения размерности общей задачи оптимизации процесса организации многоцелевого обучения предложено ее поэтапное решение. Описан подход к вычислению оценок возможности обучения специалистов по имеющимся в образовательной организации направлениям подготовки и выбора учебных модулей. В работе рассмотрены варианты оптимизации выбора модулей для подготовки специалистов по следующим критериям: минимизации общей длительности подготовки, стоимости обучения и используемых для обучения ресурсов. Предложен алгоритм, с помощью которого возможно сформировать оптимальную по составу обучающихся группу.
\end{abstract}

Ключевые слова: моделирование многочелевого обучения; направление подготовки; оптимизация; задача о назначениях.

\section{Литература}

1. Зимняя, И.А. Ключевые компетенции - новая парадигма результата образования И.А. Зимняя // Высшее образование сегодня. - 2003. - № 5. - С. 34-42.

2. Kiriakidis, P. Research in Multidimention Education / P. Kiriakidis, P. Barber, J.W. Decota.Iasi: Lumen, 2011. 
3. Kelly, K.P. Getting to the Goal in Professional Military Education / K.P. Kelly, J. JohnsonFreese // ORBIS. - 2014. - V. 58, № 1. - P. 119-131.

4. Денкс, К.А. Задача синтеза индивидуальных планов обучения в пространстве виртуальных учебных групп / К.А. Денкс, Ю.Ю. Якунин, Д.И. Ярещенко // Экономика, статистика и информатика. - 2015. - № 6. - С. 118-127.

5. Меньших, В.В. Концептуальная модель и технология обучения коллективным действиям по принятию решений при возникновении чрезвычайных обстоятельств / В.В. Меньших, Е.Н. Середа // Труды Академии управления МВД России. - 2016. - № 2. - С. 51-56.

6. Пахаренко, Н.В. Модель определения сформированности общекультурных и профессиональных компетенций / Н.В. Пахаренко, И.Н. Зольникова // Современные проблемы науки и образования. - 2012. - № 6. - URL: https://www.scienceeducation.ru/ru/article/view?id=7502 (дата обращения: 9 февраля 2018 г.)

7. Меньших, В.В. Моделирование процесса выбора траекторий обучения сотрудников органов внутренних дел действиям при чрезвычайных обстоятельствах / В.В. Меныших, Е.Н. Середа, А.Н. Копылов // Вестник Воронежского института МВД России. - 2016. № 2. - C. 203-212.

8. Бородин, Д.К. Математическое обеспечение планирования образовательного процесса / Д.К. Бородин, А.Б. Токарев // Качество. Инновации. Образование. - 2008. - № 8 (39). C. $5-14$.

9. Саати, Т. Принятие решений: Метод анализа иерархий / Т. Саати. - М.: Радио и связь, 1993. - 278 c.

10. Меньших, В.В. Модель формирования групп для ролевого обучения принятию управленческих решений / В.В. Меньших, А.Ф. Самороковский, Е.Н. Середа // Вестник Воронежского института МВД России. - 2015. - № 2. - С. 107-114.

11. Бурков, В.Н. Прикладные задачи теории графов / В.Н. Бурков, И.А. Горгидзе, С.Е. Ловецкий. - Тбилиси: Выч. центр АН ГССР, 1974. - 231 с.

Валерий Владимирович Меньших, доктор физико-математических наук, профессор, профессор кафедры «Математика и моделирование систем», Воронежский институт МВД России (г. Воронеж, Российская Федерация), menshikh@list.ru.

Елена Николаевна Середа, старший преподаватель кафедры «Математика и моделирование систем», Воронежский институт МВД России (г. Воронеж, Российская Федерация), sereda-en@mail.ru.

Поступила в редакиию 25 января 2018 г. 